\title{
Genetic diversity of North American isolates of Renibacterium salmoninarum
}

\author{
Clifford E. Starliper* \\ U.S. Geological Survey, Biological Resources Division**, Leetown Science Center, National Fish Health Research Laboratory, \\ 1700 Leetown Road, Kearneysville, West Virginia 25430, USA
}

\begin{abstract}
Genetic diversity of Renibacterium salmoninarum was evaluated by multilocus enzyme electrophoresis (MEE). Whole cell lysates were prepared for 40 isolates representing 5 groups based on host and geographic area. Each lysate was assessed for activity of 44 enzymes with a pH 6.5 aminecitrate and a $\mathrm{pH} 8.0$ buffer. Genetic variation was scored at 26 loci. Two zones of activity (presumptive loci) were scored each for esterase (EC 3.1.1.1) and glycyl-leucine peptidase (EC 3.4.11.x). There were no monomorphic loci and there was an average of 2.65 electromorphs per locus. There were 21 electrophoretic types. Mean genetic diversity $\left(H_{T}\right)$ was 0.161 and the percentage of this explained by diversity between groups was $G_{51}=8.1 \%$; thus $91.9 \%$ of the genetic diversity was due to heterogeneity between individual isolates. The 2 groups with the highest genetic diversity were from chinook Oncorhynchus tshawytscha and coho O. kisutch salmon, both from the Manistee Weir, Michigan, USA; i.e. 0.270 and 0.298 , respectively. The highest genetic diversity for a locus $\left(h_{T}\right)$ was 0.587 for EST-1. At this locus, diversity between groups explained a higher percentage of the total diversity $\left(G_{51}=36.5 \%\right)$. Other loci with relatively high genetic diversity were succinate dehydrogenase $(0.385 ; \mathrm{EC} 1.3 .99 .1)$, cytochrome coxidase $(0.273$; EC 1.9 .3 .1$)$ and aconitase $(0.311 ;$ EC 4.2 .1 .3$)$. The results of this study indicate relatively low genetic diversity of $R$. salmoninarum.
\end{abstract}

KEY WORDS: Genetic diversity $\cdot$ Renibacterium salmoninarum Electromorphs $\cdot$ Multilocus enzyme electrophoresis Bacterial kidney disease

\section{INTRODUCTION}

Renibacterium salmoninarum is the Gram-positive bacillus that causes bacterial kidney disease (BKD), a significant cause of mortality among salmonid fish (Sanders \& Fryer 1980). Previous serological studies have shown strains of this bacterium to be antigenically homogeneous (Bullack et al. 1974, Getchell et al. 1985). Additionally, strains of $R$. salmoninarum were similar in their lack of extracellular biological activity (Bandin et al. 1991). On the other hand, Austin \& Rodgers (1980) demonstrated the existence of 2 distinct phena by evaluation of biochemical, serological and physiological studies. More recently, Bandin et al. (1992) suggested the existence of 2 antigenically distinct groups of $R$. salmoninarum based on quantitative

•E-mail: cliff_starliper@nbs.gov

- Formerly National Biological Service slide agglutination and Western blot assays. However, the authors point out that it is possible that their group of 3 isolates with a major protein of $30 \mathrm{kDa}$ could have been a result of the instability of the major soluble antigen ( $57 \mathrm{kDa}$ protein) of $R$. salmoninarum as described by Griffiths \& Lynch (1991).

The purpose of this study was to evaluate the presence and mobility of enzymatic activity for a representative number of Renibacterium salmoninarum isolates from hosts showing clinical signs of BKD. Multilocus enzyme electrophoresis (MEE) was used and the degree of genetic diversity determined.

\section{METHODS}

The isolates of Renibacterium salmoninarum used in this study represented 5 groups (isolate origins) based on host and geographic location (Table 1). The groups were: various hosts from the Pacific northwest 
Table 1. Renibacterium salmoninarum. List of 40 isolates evaluated by multilocus enzyme electrophoresis

\begin{tabular}{|lll|}
\hline Group & Host & Isolate \\
\hline Pacific Northwest (USA and Canada) & $\begin{array}{l}\text { Oncorhynchus tshawytscha } \\
\text { O. kisutch } \\
\text { Salmo salar } \\
\text { Not known }\end{array}$ & $\begin{array}{l}7.29,7.30,7.32, \text { ATCC 33209, RB-1-73 } \\
384, \text { Siletz } \\
\text { RS18 }\end{array}$ \\
Manistee Weir, Michigan, USA & O. kisutch & Quinalt, Salmon Creek \\
Manistee Weir, Michigan, USA & O. tshawytscha & MCO1, MCO3, MCO4M, MCO5, MCO9, MCO11 \\
& MCK4M, MCK26, MCK30, MCK32, MCK38, \\
Kewanee Weir, Wisconsin, USA & O. tshawytscha & MCK49, MCK50, MCK52M, MCK56, MCK60M \\
Strawberry Creek Wier, Wisconsin, USA & O. tshawytscha & A.5, A12, A18, A22, A24M, A34, A40, A57 \\
aGroups were based on host and geographic area of bacterial isolation & B6, B13, B26, B49, B51, B58 \\
'RS18 was from Nova Scotia and the only eastern North America representative; for data analysis this isolate was placed \\
with isolates from the Pacific Northwest origin
\end{tabular}

(PNW); chinook salmon Oncorhynchus tshawytscha from the Manistee Weir, Michigan, USA (MCK); coho salmon $O$. kisutch from the Manistee Weir, Michigan (MCO); chinook salmon from the Kewanee Weir, Wisconsin, USA (A strains); and chinook salmon from the Strawberry Creek Weir, Wisconsin (B strains). One strain (RS18) was taken from an Atlantic salmon Salmo salar in Nova Scotia, Canada. Because this was the sole representative of this geographic area, for statistical analysis it was placed with the isolates from the PNW, the group having the most diverse number of hosts and sites. The PNW strains were maintained in the culture collection of the National Fish Health Research Laboratory (Kearneysville, WV, USA). The Michigan and Wisconsin origin strains were isolated in 1991 and 1992 from Lake Michigan returning broodstock displaying clinical signs of BKD (Bullock \& Herman 1988, Fryer \& Lannan 1993). These strains were isolated from kidney tissue by inoculation onto KDM2 (Evelyn 1977) prepared with and without 1\% metabolite (Evelyn et al. 1990) Colonies were transferred to KDM2 slants and subsequent growth rinsed with fresh KDM2 broth medium and frozen at $-70^{\circ} \mathrm{C}$.

Preparation of whole cell lysates. A frozen aliquot of each isolate was used to inoculate $500 \mathrm{ml}$ KDM2 broth supplemented with $1 \%$ metabolite. The culture was incubated on a shaker $(100 \mathrm{rpm})$ for 2 to $3 \mathrm{wk}$ at $15^{\circ} \mathrm{C}$ (New Brunswick Scientific G25R, Edison, NJ, USA). Purity of each culture was ensured by Gram stain, lack of growth on brain heart infusion agar (Difco), and the identity confirmed by the fluorescent antibody test (Bullock et al. 1980). Cells were collected by centrifugation $(4100 \times g)$ for $30 \mathrm{~min}$ at $4^{\circ} \mathrm{C}$ (Sorvall RC2-B, Newtown, CT, USA). The cells were suspended in $15 \mathrm{ml}$ of a lysate buffer $(10 \mathrm{mM}$ Tris, $1 \mathrm{mM}$ EDTA, pH 6.8; Selander et al. 1986), centrifuged as before and resuspended in $5 \mathrm{ml}$ of lysate buffer. The cells were sonicated with $1 \mathrm{~min}$ bursts (5 total), while in an ice bath, using a Cole Parmer 4710 ultrasonic homogenizer (Chicago, IL, USA) set to deliver $50 \mathrm{~W} \mathrm{~cm} \mathrm{~cm}^{-1}$. Debris was removed by centrifugation $(13000 \times g)$ for $30 \mathrm{~min}$ at $4^{\circ} \mathrm{C}$. The supernatant (whole cell lysate) was placed into 5 vials and frozen at $-70^{\circ} \mathrm{C}$.

Electrophoresis of whole cell lysates. Procedures employed for electrophoresis were previously described by Selander et al. (1986) using 11 to $11.5 \%$ hydrolyzed starch (Sigma). Prior to preparing the gels, the starch was passed through a $200 \mu \mathrm{m}$ sieve to remove any particulate material. Two buffer systems were used to evaluate the isolates for each enzyme, a pH 6.5 amine-citrate (AC; Clayton \& Tretiak 1972) and a pH 8.0 buffer (RW; Ridgway et al. 1970). An isolate (B58) was used on all gels as a control (100 allele) to adjust gel to gel mobility differences. Duration of electrophoresis was 3 to $4 \mathrm{~h}$.

Enzyme staining. Recipes for the staining solutions have been described by Shaw \& Prasad (1970), Harris \& Hopkinson (1976), Allendorf et al. (1977), Schill et al. (1984), and Manchenko (1994). For each stain, the gel slice was placed into the stain mixture and incubated at $37^{\circ} \mathrm{C}$ for a sufficient time to allow visualization of positively stained bands. A list of the enzymes used to assay the genetic diversity of Renibacterium salmoninarum is presented in Table 2 .

Data analysis. Isolate zones of activity were scored by measuring the distance the zone had migrated from the origin. Each distance value was converted to a mobility relative to a 100 electromorph, and isolate B58 was designated the 100 electromorph. The enzyme mobility isolate profiles were evaluated and genetic diversity calculated in accordance with described methods (Nei 1977, 1978, Selander et al. 1986). Genetic diversity $(h)$ was calculated using the equa- 
Table 2. List of enzyme loci used to evaluate the genetic diversity of strains of Renibacterium salmoninarum. Buffer system used for scoring: $\mathrm{AC}=\mathrm{pH} 6.5$ (Clayton \& Tretiak 1972); $\mathrm{RW}=\mathrm{pH} 8.0$ (Ridgway et al. 1970 ). NA = no activity noted

\begin{tabular}{|c|c|c|}
\hline $\begin{array}{l}\text { EC } \\
\text { number }\end{array}$ & Enzyme & $\begin{array}{l}\text { Buffer } \\
\text { system }\end{array}$ \\
\hline 1.1.1.1 & Alcohol $\mathrm{DH}^{a}(\mathrm{ADH})$ & NA \\
\hline 1.1 .1 .8 & Glycerol-3-phosphate DH (GPD) & NA \\
\hline 1.1 .1 .14 & Sorbitol DH (SORDH) & NA \\
\hline 1.1 .1 .27 & Lactate DH (LDH) & NA \\
\hline 1.1 .1 .37 & Malate $\mathrm{DH}(\mathrm{MDH})$ & NA \\
\hline 1.1 .1 .40 & Malic enzyme (ME) & NA. \\
\hline 1.1 .1 .42 & Isocitrate DH (ICD) & $\mathrm{AC}$ \\
\hline 1.1 .1 .44 & Phosphogluconate DH (PGD) & $\mathrm{AC}$ \\
\hline 1.1 .1 .47 & Glucose DH (GDH) & NA \\
\hline 1.1 .1 .49 & Glucose-6-phosphate DH (GD) & $\mathrm{AC}$ \\
\hline 1.1 .1 .204 & Xanthine DH (XDH) & NA \\
\hline 1.2 .1 .12 & \multicolumn{2}{|l|}{ Glyceraldehyde-3-phosphate DH (GAPDH) AC } \\
\hline 1.3 .99 .1 & Succinate DH (SUCDH) & RW \\
\hline 1.4 .1 .1 & Alanine DH (ALADH) & $\mathrm{AC}$ \\
\hline 1.4 .1 .9 & Leucine DH (LEUDH) & NA \\
\hline $1.4 .1 .2-4$ & Glutamate DH (GLUD) & RW \\
\hline 1.8 .1 .4 & Diaphorase (DIA) & $\mathrm{AC}$ \\
\hline 1.6 .99 .2 & Menadione reductase (MR) & $\mathrm{AC}$ \\
\hline 1.9 .3 .1 & Cytochrome c oxidase (CTO) & $\mathrm{AC}$ \\
\hline 1.15 .1 .1 & Superoxide dismutase (SOD) & $\mathrm{AC}$ \\
\hline 2.4 .2 .1 & Nucleoside phosphorylase (NP) & RW \\
\hline 2.6 .1 .24 & Tyrosine aminotransferase (ATRANS) & NA \\
\hline 2.6 .1 .1 & Aspartate aminotransferase (AAT) & RW \\
\hline 2.7 .1 .1 & Hexokinase (HK) & RW \\
\hline 2.7 .3 .2 & Creatine kinase (CK) & RW \\
\hline 2.7 .4 .3 & Adenylate kinase (AK) & RW \\
\hline 3.1 .1 .1 & Esterase (EST-1, EST-2) & $\mathrm{AC}$ \\
\hline 3.1 .3 .1 & Alkaline phosphatase (ALP) & RW \\
\hline 3.1 .3 .2 & Acid phosphatase (ACP) & NA \\
\hline 3.1 .3 .11 & Fructose bisphosphatase (FBP) & $\mathrm{NA}$ \\
\hline 3.2 .1 .52 & Hexosaminidase (HEX) & $\mathrm{NA}$ \\
\hline 3.2 .1 .31 & $\beta$-Glucuronidase (GUS) & NA \\
\hline $3.4 .11 . \mathrm{x}$ & Peptidases & \\
\hline & Glycyl-leucine (GLPEP-1, GLPEP-2) & RW \\
\hline & Leucyl-glycyl-glycine (LGGPEP) & NA \\
\hline 3.5 .4 .3 & Guanine deaminase (GDA) & NA \\
\hline 3.5.4.4 & Adenosine deaminase (ADA) & NA \\
\hline 4.1 .1 .31 & Phosphoenolpyruvate carboxylase (PC) & NA \\
\hline 4.1 .2 .13 & A.ldolase (ALD) & NA \\
\hline 4.2 .1 .2 & Fumarate hydratase $(F H)$ & $\mathrm{AC}$ \\
\hline 4.2 .1 .3 & Aconitase $(\mathrm{ACO})$ & RW \\
\hline 5.3 .1 .1 & Triosephosphate isomerase (TPI) & NA \\
\hline 5.3 .1 .8 & Mannose-6-phosphate isomerase (MPI) & RW \\
\hline 5.3 .1 .9 & Glucose-6-phosphate isomerase (GPI) & $\mathrm{AC}$ \\
\hline 5.4 .2 .2 & Phosphoglucomutase (PGM) & $\mathrm{AC}$ \\
\hline
\end{tabular}

tion: $h=\left(1-\sum x_{i}^{2}\right)(n / n-1)$, where $n$ is the number of isolates and $x_{1}$ is the frequency of the electromorph. Genetic diversity was calculated for each locus $\left(h_{\mathrm{T}}\right)$ and was determined for each group at each locus. Mean genetic diversity $\left(H_{\Upsilon}\right)$ was calculated as the average of all $h_{\Upsilon}$.

\section{RESULTS}

Forty-four enzyme staining systems were used to assay genetic variation in all of the Renibacterium salmoninarum isolates electrophoretically separated on the AC and RW buffer systems. No enzyme activity was detected with 20 of these, after 2 attempts with both buffer systems (Table 2). Two zones of activity (presumptive loci) were observed for the enzymes GLPEP and EST; for these, the 2 loci were designated 1 and 2 , representing slow and fast mobilities, respectively. Both EST-1 and EST-2 were active when either $\alpha$-naphthyl or $\beta$-naphthyl acetate was used as the substrate. In 3 enzymes activity was detected in only 1 or 2 isolates: PGM (MCK49, MCK56); GD (MCK49); and GLUD (Salmon Creek).

Genetic diversity was determined for 40 Renibacterium salmoninarum isolates using 26 loci. Electromorph mobilities and the frequencies of each are given in Table 3. There were no monomorphic loci and there was an average of 2.65 electromorphs per locus. The number of electromorphs per locus by group was: PNW (1.23), MCO (1.77), MCK (2.12), A (1.27), and B (1.15).

Genetic diversity (h) values for each isolate origin group at each locus are presented in Table 4 . The highest locus genetic diversity was recorded for EST-1 $\left(h_{\mathrm{T}}=\right.$ 0.587 ). Of the 40 isolates 23 displayed the 100 electromorph at EST-1 (Table 3); however, 9 of the 10 PNW isolates had an electromorph which was $35 \%$ faster and only 6 other isolates had this 135 electromorph. For EST-1, the proportion of genetic diversity that is explained by variation between groups $\left(G_{\mathrm{st}}\right)$ was $36.5 \%$. Other loci that had relatively high genetic diversity were SUCDH (0.385), CTO (0.273), and ACO (0.311).

Mean genetic diversity $\left(H_{\mathrm{T}}\right)$ of all isolates over the 26 loci was 0.161 . The percentage of the mean genetic diversity calculated to be due to variability between isolate origin groups was $G_{51}=8.1 \%$; therefore, $91.9 \%$ of the genetic diversity of the 40 Renibacterium salmoninarum isolates was due to differences between individual isolates. Mean genetic diversity of the groups was highest for the isolates from Michigan origin, MCO (0.298) and MCK (0.270) (Table 4). Genetic diversity for the PNW group was 0.058 and for the 2 groups of Wisconsin origin were: $A(0.067)$ and $B$ $(0.051)$.

At 11 of the loci (GD, GAPDH, ALADH, GLUD, DIA, SOD, NP, AAT, ALP, GPI, PGM), only 1 or 2 of the 40 isolates showed variation. For SOD, the most prominent and resolved zone of activity (allele) was scored. Other SOD activity was present but resolution was not sufficient for accurate analysis; thus, variability at the SOD locus, if present, could not be determined. 
The isolates comprised 21 electrophoretic types (ETs). Two ETs were represented by 9 and 10 isolates each and these differed at 1 locus, EST-1. Isolates of these 2 ETs were from all 5 groups. Seven- teen of 21 ETs were represented by single isolates, many of which differed at only 1 locus and this is indicated by the low $H_{\mathrm{T}}$ relative to the ET:isolate ratio $(21: 40)$.

Table 3. Renibacterium salmoninarum. Electromorph frequencies of 5 groups of isolates scored at 26 loci. Isolate origins: PNW $=$ Pacific Northwest; $\mathrm{MCO}=$ Michigan coho $\mathrm{MCK}=$ Michigan chinook; $\mathrm{A}=$ Kewanee, Wisconsin, chinook $\mathrm{B}=$ Strawberry Creek, Wisconsin, chinook

\begin{tabular}{|c|c|c|c|c|c|c|c|c|c|c|c|}
\hline \multirow{2}{*}{$\begin{array}{l}\text { Locus and } \\
\text { electromorph }\end{array}$} & \multicolumn{5}{|c|}{ Isolate origins } & \multicolumn{2}{|l|}{ Locus and } & \multicolumn{4}{|c|}{ Isolate origins } \\
\hline & PNW & $\mathrm{MCO}$ & $\mathrm{MCK}$ & A & B & electromorph $h^{\sharp}$ & PNW & $\mathrm{MCO}$ & MCK & A & $B$ \\
\hline$I C D$ & & & & & & $\mathrm{CK}$ & & & & & \\
\hline 100 & 1.000 & 0.833 & 0.800 & 1.000 & 1.000 & 100 & 1.000 & 0.833 & 0.900 & 0.875 & 1.000 \\
\hline 0 & & 0.167 & 0.200 & & & 0 & & 0.167 & & 0.125 & \\
\hline PGD & & & & & & $180 / 100$ & & & 0.100 & & \\
\hline 100 & 1.000 & 0.833 & 0.800 & 1.000 & 1.000 & $\mathrm{AK}$ & & & & & \\
\hline 0 & & 0.167 & 0.100 & & & 100 & 1.000 & 0.833 & 0.900 & 0.875 & 1.000 \\
\hline 108 & & & 0.100 & & & 0 & & 0.167 & & 0.125 & \\
\hline GD & & & & & & $180 / 100$ & & & 0.100 & & \\
\hline 100 & & & 0.100 & & & EST-1 & & & & & \\
\hline 0 & 1.000 & 1.000 & 0.900 & 1.000 & 1.000 & 100 & 0.100 & 0.667 & 0.500 & 1.000 & 0.833 \\
\hline GAPDH & & & & & & 0 & & 0.167 & & & \\
\hline 100 & 1.000 & 1.000 & 0.800 & 1.000 & 1.000 & 135 & 0.900 & 0.167 & 0.200 & & \\
\hline 91 & & & 0.100 & & & $135 / 100$ & & & 0.200 & & 0.167 \\
\hline $100 / 91$ & & & 0.100 & & & $\begin{array}{l}159 \\
\text { EST-2 }\end{array}$ & & & 0.100 & & \\
\hline SUCDH & & & 0600 & 0875 & 0.833 & $\begin{array}{l}\text { EST-2 } \\
100\end{array}$ & 1.000 & 0.667 & 0.900 & 1.000 & 1.000 \\
\hline $\begin{array}{l}100 \\
0\end{array}$ & 1.000 & $\begin{array}{l}0.333 \\
0.667\end{array}$ & $\begin{array}{l}0.600 \\
0.400\end{array}$ & 0.125 & 0.167 & 0 & & 0.333 & 0.100 & & \\
\hline ALADH & & & & & & ALP & & & & & \\
\hline 100 & 0.900 & 0.833 & 1.000 & 1.000 & 1.000 & 100 & 1.000 & 1.000 & 0.900 & 1.000 & 1.000 \\
\hline $\begin{array}{l}0 \\
97\end{array}$ & & 0.167 & & & & & & & 0.100 & & \\
\hline $\begin{array}{l}97 \\
\text { GLUD }\end{array}$ & 0.100 & & & & & GLPEP-1 & & & & & \\
\hline $\begin{array}{l}\text { GLUD } \\
100\end{array}$ & & & & & & 100 & 1.000 & 0.667 & 0.900 & 0.875 & 1.000 \\
\hline $\begin{array}{l}100 \\
0\end{array}$ & $\begin{array}{l}0.100 \\
0.900\end{array}$ & & & & & 0 & & 0.333 & & 0.125 & \\
\hline DIA & 0.900 & 1.000 & 1.000 & 1.000 & 1.000 & 120 & & & 0.100 & & \\
\hline 100 & 1.000 & 1000 & & 1000 & 1000 & $\begin{array}{l}\text { GLPEP-2 } \\
100\end{array}$ & 1000 & 0667 & 0.800 & 1000 & 1000 \\
\hline 0 & & 1.000 & 0.100 & 1.000 & 1.000 & $\begin{array}{l}100 \\
0\end{array}$ & 1.000 & 0.333 & 0.200 & 1.000 & 1. 000 \\
\hline MR & & & & & & $\mathrm{FH}$ & & & & & \\
\hline $\begin{array}{l}100 \\
167 / 73\end{array}$ & 1.000 & 1.000 & 0.600 & 1.000 & 1.000 & 100 & 1.000 & 0.667 & 0.900 & 1.000 & 1.000 \\
\hline $\begin{array}{l}167 / 73 \\
87\end{array}$ & & & 0.100 & & & $\begin{array}{l}0 \\
\mathrm{ACO}\end{array}$ & & & & & \\
\hline 87 & & & 0.300 & & & $\begin{array}{l}\mathrm{ACO} \\
100\end{array}$ & & 0.667 & 0.800 & & \\
\hline CTO & & & & & & $\begin{array}{l}100 \\
0\end{array}$ & 0.800 & $\begin{array}{l}0.667 \\
0.167\end{array}$ & $\begin{array}{l}0.800 \\
0.200\end{array}$ & 0.875 & 1.000 \\
\hline $\begin{array}{l}100 \\
0\end{array}$ & 0.800 & 0.833 & 0.900 & 0.875 & 0.833 & $\begin{array}{l}0 \\
100 / 79\end{array}$ & 0.200 & 0.167 & & 0.125 & \\
\hline 0 & & 0.167 & & & & $\begin{array}{l}100 / 79 \\
\text { MPI }\end{array}$ & & & & & \\
\hline $100 / 85$ & 0.200 & & & 0.125 & 0.167 & $\begin{array}{l}\text { MPI } \\
100\end{array}$ & 0.900 & 0.667 & & & \\
\hline 112 & & & 0.100 & & & $\begin{array}{l}100 \\
0\end{array}$ & 0.100 & 0.333 & $\begin{array}{l}0.800 \\
0.200\end{array}$ & 1.000 & 1.000 \\
\hline SOD & & & & & & $\begin{array}{l}0 \\
\mathrm{GPI}\end{array}$ & & & & & \\
\hline 100 & 1.000 & 0.833 & 0.900 & 1.000 & 1.000 & $\begin{array}{l}\text { GPI } \\
100\end{array}$ & 1000 & 0833 & & & \\
\hline 0 & & 0.167 & & & & $\begin{array}{l}100 \\
0\end{array}$ & 1.000 & $\begin{array}{l}0.033 \\
0.167\end{array}$ & 0.900 & 1.000 & 1.000 \\
\hline 97 & & & 0.100 & & & $\begin{array}{l}0 \\
65\end{array}$ & & 0.167 & & & \\
\hline NP & & & & & & 65 & & & 0.100 & & \\
\hline 100 & 1.000 & 0.833 & 0.900 & 1.000 & 1.000 & PGM & & & & & \\
\hline 0 & & 0.167 & & & & 100 & & & 0.100 & & \\
\hline 90 & & & 0.100 & & & 0 & 1.000 & 1,000 & 0.800 & 1.000 & 1.000 \\
\hline AAT & & & & & & 460 & & & 0.100 & & \\
\hline 100 & 1.000 & 1.000 & 0.900 & 1.000 & 1.000 & & & & & & \\
\hline 85 & & & 0.100 & & & ${ }^{a}$ Each electrom & horph & he phe & typic e & ression & f the iso- \\
\hline HK & & & & & & late at that loce & us anc & escore & the $m$ & Gity re & ve to the \\
\hline 100 & 1.000 & 0.833 & 1.000 & 0.875 & 0.833 & selected contro & lor 100 & Ilele; B5 & was the & ontrol ur & essitwas \\
\hline 0 & & 0.167 & & 0.125 & 0.167 & null (i.e. GD); th & hen anc & herisola & e was se & ected for & hat locus \\
\hline
\end{tabular}


Table 4. Renibacterium salmoninarum. Genetic diversity of 40 isolates evaluated with 26 loci. For abbreviations of isolate origins, see Table $3 . H_{\mathrm{S}}$ : sample genetic diversity; $H_{\mathrm{T}}$ : mean genetic diversity

\begin{tabular}{|c|c|c|c|c|c|c|c|}
\hline Locus & PNW & $\mathrm{MCO}$ & MCK & A & B & Group & Total \\
\hline$I C D$ & 0.0 & 0.334 & 0.356 & 0.0 & 0.0 & 0.139 & 0.142 \\
\hline PGD & 0.0 & 0.334 & 0.378 & 0.0 & 0.0 & 0.145 & 0.145 \\
\hline GD & 0.0 & 0.0 & 0.200 & 0.0 & 0.0 & 0.050 & 0.050 \\
\hline GAPDH & 0.0 & 0.0 & 0.378 & 0.0 & 0.0 & 0.095 & 0.099 \\
\hline SUCDH & 0.0 & 0.533 & 0.533 & 0.250 & 0.334 & 0.313 & 0.385 \\
\hline ALADH & 0.200 & 0.334 & 0.0 & 0.0 & 0.0 & 0.100 & 0.099 \\
\hline GLUD & 0.200 & 0.0 & 0.0 & 0.0 & 0.0 & 0.050 & 0.050 \\
\hline DIA & 0.0 & 0.0 & 0.200 & 0.0 & 0.0 & 0.050 & 0.050 \\
\hline MR & 0.0 & 0.0 & 0.600 & 0.0 & 0.0 & 0.150 & 0.188 \\
\hline $\mathrm{CTO}$ & 0.356 & 0.334 & 0.200 & 0.250 & 0.334 & 0.289 & 0.273 \\
\hline SOD & 0.0 & 0.334 & 0.200 & 0.0 & 0.0 & 0.100 & 0.099 \\
\hline NP & 0.0 & 0.334 & 0.200 & 0.0 & 0.0 & 0.100 & 0.099 \\
\hline AAT & 0.0 & 0.0 & 0.200 & 0.0 & 0.0 & 0.050 & 0.050 \\
\hline $\mathrm{HK}$ & 0.0 & 0.334 & 0.0 & 0.250 & 0.334 & 0.150 & 0.142 \\
\hline CK & 0.0 & 0.334 & 0.200 & 0.250 & 0.0 & 0.150 & 0.145 \\
\hline $\mathrm{AK}$ & 0.0 & 0.334 & 0.200 & 0.250 & 0.0 & 0.150 & 0.145 \\
\hline EST-1 & 0.200 & 0.599 & 0.733 & 0.0 & 0.334 & 0.373 & 0.587 \\
\hline EST-2 & 0.0 & 0.533 & 0.200 & 0.0 & 0.0 & 0.130 & 0.142 \\
\hline ALP & 0.0 & 0.0 & 0.200 & 0.0 & 0.0 & 0.050 & 0.050 \\
\hline GLPEP-1 & 0.0 & 0.533 & 0.200 & 0.250 & 0.0 & 0.180 & 0.188 \\
\hline GLPEP-2 & 0.0 & 0.533 & 0.356 & 0.0 & 0.0 & 0.169 & 0.185 \\
\hline $\mathrm{FH}$ & 0.0 & 0.533 & 0.200 & 0.0 & 0.0 & 0.130 & 0.145 \\
\hline $\mathrm{ACO}$ & 0.356 & 0.599 & 0.356 & 0.250 & 0.0 & 0.318 & 0.311 \\
\hline MPI & 0.200 & 0.533 & 0.356 & 0.0 & 0.0 & 0.219 & 0.224 \\
\hline GPI & 0.0 & 0.334 & 0.200 & 0.0 & 0.0 & 0.100 & 0.099 \\
\hline PGM & 0.0 & 0.0 & 0.378 & 0.0 & 0.0 & 0.095 & 0.099 \\
\hline $\begin{array}{l}\text { Mean genetic } \\
\text { diversity }\end{array}$ & 0.058 & 0.298 & 0.270 & 0.067 & 0.051 & $H_{\mathrm{S}}=0.148$ & $H_{\mathrm{T}}=0.161$ \\
\hline
\end{tabular}

\section{DISCUSSION}

MEE has been shown to offer estimates of bacterial population genetic diversity similar to results using DNA hybridization studies (Gilmour et al. 1987). Such analysis also provides a relatively inexpensive method to determine genotypic profiles for a large number of isolates (Manchenko 1994). Homogeneity of individuals is determined by statistically evaluating the isolate profiles, which has been done for a number of bacterial species including Campylobacter spp. (Aeschbacher \& Piffaretti 1989), Legionella pneumophila (Selander et al. 1985), Mycobacteria (Wasem et al. 1991) and some Salmonella spp. (Reeves et al. 1989). The genetic diversity of certain fish pathogenic bacteria has also been evaluated using MEE: Aeromonas salmonicida (Boyd et al. 1994), Edwardsiella ictaluri (Starliper et al. 1988) and Yersinia ruckeri (Schill et al. 1984).

In this study of Renibacterium salmoninarum isolates from various origins, the mean genetic diversity $\left(H_{\mathrm{T}}=\right.$ 0.161) was relatively low and comparable to other genetically homogeneous bacteria such as Vibrio anguillarum and $V$. ordalii $\left(H_{\mathrm{T}}=0.130\right.$; Starliper et al.
1989); and Bordetella spp. $\left(H_{\mathrm{T}}=0.284\right.$; Musser et al. 1986). However, $H_{\mathrm{T}}$ of $R$. salmoninarum was greater than that determined for 2 other fish pathogenic bacteria, namely Aeromonas salmonicida $\left(H_{\top}=0.037\right.$; Boyd et al. 1994) and Yersinia ruckeri $\left(H_{\mathrm{T}}=0.014\right.$; Schill et al. 1984)

Absence of enzyme activity, denoted as null, may result not only result from a bacterium lacking an allele at a particular locus, but could reflect insufficient enzyme concentration in the whole cell lysate or use of an inappropriate buffer system to detect activity of a particular enzyme (Selander et al. 1986). Two of the most frequently used buffer systems were used in the present study. It is possible that another buffer system. might detect activity in some of the enzymes which had no positive isolates in this study.

Noteworthy was the activity of CTO in the Renibacterium salmoninarum isolates using the MEE technique. To determine CTO, $\mathrm{N}, \mathrm{N}$-dimethyl-p-phenylenediamine was used as the substrate and the activity developed for visualization by addition of $\alpha$-naphthol to the staining solution. The visible product of the reaction was indophenol blue. It has been previously reported that $R$. salmoninarum is cytochrome oxidase 
negative when the standard biochemical method is used for determination (Sanders \& Fryer 1980). This contrast in results could be explained by the difference in the preparation of the whole cell lysates for the MEE method of CTO determination. With MEE, the cells were disrupted by sonication, perhaps releasing the enzyme into the lysate solution. Using the standard biochemical method which employs colonial growth, the cells remain intact.

Mean genetic diversity for each of the isolate origins was greatest for the MCO and MCK groups (Table 4). To determine if the isolates of Michigan origins were different from the rest and, perhaps, explain a portion of the mean genetic diversity, the 40 isolate profiles were regrouped-all strains of Michigan origin in one group and all other strains in another. Frequencies and genetic diversity values were recalculated (data not presented). Using this grouping, there was no activity of any Michigan strains at the GLUD locus, and there was variation at all other loci. For the group with strains from the other 3 origins, there were 13 monomorphic loci and 2 (GD, PGM) were void of detectable enzyme activity. The number of monomorphic loci detected among the isolates when strains were placed in 2 groups contrasts to that in the 5 groups, in which no monomorphic loci were scored. With 2 groups, the mean genetic diversity $\left(H_{\mathrm{T}}\right)$ remains the same as with 5 groups, and if a larger percentage of the total genetic diversity explained by group differences $\left(G_{\mathrm{s} t}\right)$ became evident, the sample genetic diversity $\left(H_{\mathrm{S}}\right)$ would be reduced. However, with the isolates in 2 groups, the $H_{S}$ actually increased to 0.154 , from 0.148 , for the isolates placed into 5 groups. Accordingly, $G_{\mathrm{st}}$ for the 2 group arrangement was reduced to $4.3 \%$, from $8.1 \%$, for the 5 groups. The results of this study are indicative of relatively low genetic diversity of Renibacterium salmoninarum. Furthermore, the genetic diversity present within the species is explained by variability among isolates regardless of their origin and not by differences between groups based on their host and geographic origin.

Acknowledgements. Appreciation is extended to Mr John G. Hnath of the Michigan Department of Natural Resources, Dr Sue Marcquenski and Ms Kristi Meyer of the Wisconsin Department of Natural Resources for assistance in collection of the bacteria. Also, thanks to Mr Stevan R. Phelps of the Washington Department of Fish and Wildlife, Mr William B. Schill of the National Fish Health Research Laboratory and Dr G. L. Bullock of the Freshwater Institute for their critical reviews.

\section{LITERATURE CITED}

Aeschbacher M, Piffaretti JC (1989) Population genetics of human and animal Campylobacter strains. Infect Immun $57: 1432-1437$
Allendorf FM, Mitchell N, Ryman N, Stahl C (1977) Isozyme loci in brown trout (Salmo trutta L): detection and interpretation from population data. Hereditas 86:179-190

Austin B, Rodgers CJ (1980) Diversity among strains causing bacterial kidney disease in salmonid fish. Curr Microbiol $3: 231-235$

Bandin I, Santos Y, Bruno DW, Raynard RS, Toranzo AE, Barja JL (1991) Lack of biological activities in the extracellular products of Renibacterium salmoninarum. Can J Fish Aquat Sci 48:421-425

Bandin I, Santos Y, Magarinos B, Barja JL, Toranzo AE (1992) The detection of two antigenic groups among Renibacterium salmoninarum isolates. FEMS Microbiol Lett 94: $105-110$

Boyd EF, Hiney MP, Peden JF, Smith PR, Caugant DA (1994) Assessment of the genetic diversity among Aeromonas salmonicida isolates by multilocus enzyme electrophoresis. J Fish Dis 17:97-98

Bullock GL, Griffin BR, Stuckey HM (1980) Detection of Corynebacterium salmoninus by direct fluorescent antibody test. Can J Fish Aquat Sci 37:719-721

Bullock GL, Herman RL (1988) Bacterial kidney disease of salmonid fishes caused by Renibacterium salmoninarum. US Department of Interior, USFWS Fish Disease Leaflet No 78, Washington, DC

Bullock GL, Stuckey HM, Chen PK (1974) Corynebacterial kidney disease of salmonids: growth and serological studies on the causative bacterium. Appl Microbiol 28: $811-814$

Clayton JW, Tretiak DN (1972) Amine citrate buffers for $\mathrm{pH}$ control in starch gel electrophoresis. J Fish Res Bd Can 29: $1169-1172$

Evelyn TPT (1977) An improved growth medium for the kidney disease bacterium and some notes on using the medium. Bull Off Int Epiz 87:511-513

Evelyn TPT, Prosperi-Porta L, Ketcheson JE (1990) Two new techniques for obtaining consistent results when growing Renibacterium salmoninarum on KDM2 culture medium. Dis Aquat Org 9:209-212

Fryer JL, Lannan CN (1993) The history and current status of Renibacterium salmoninarum, the causative agent of bacterial kidney disease in Pacific salmon. Fish Res 17:15-33

Getchell RG, Rohovec JS, Fryer JL (1985) Comparison of Renibacterium salmoninarum isolates by antigenic analysis. Fish Pathol 20:149-159

Gilmour MN, Whittam TS, Kilian M, Selander RK (1987) Genetic relationships among the oral streptococci. J Bacteriol 169:5247-5257

Griffiths SG, Lynch WH (1991) Instability of the major soluble antigen produced by Renibacterium salmoninarum. J Fish Dis 14:55-66

Harris H, Hopkinson DA (1976) Handbook of enzyme electrophoresis in human genetics, 1st edn. North Holland Publishing $\mathrm{Co}_{1}$ Amsterdam

Manchenko GP (1994) Handbook of detection of enzymes on electrophoresis gels. CRC Press Inc, Boca Raton, FL

Musser JM, Hewlett EL, Peppler MS, Selander RK (1986) Genetic diversity and relationships in populations of Bordetella spp. J Bacteriol 166:230-237

Nei $M(1977) F$-statistics and analysis of gene diversity in subdivided populations. Ann Hum Genet 41:225-233

Nei $M$ (1978) Estimation of average heterozygosity and genetic distance from a small number of individuals. Genetics 89:583-590

Reeves MW, Evins GM, Heiba AA, Plikaytis BD, Farmer III JJ (1989) Clonal nature of Salmonella typhi and its genetic relatedness to other Salmonellae as shown by multilocus 
enzyme electrophoresis, and proposal of Salmonella bongori comb. nov. J Clin Microbiol 27:313-320

Ridgway GJ, Sherburne SW, Lewis RD (1970) Polymorphism in the esterases of Atlantic herring. Trans Am Fish Soc 99: $147-151$

Sanders JE, Fryer JL (1980) Renibacterium salmoninarum gen. nov., sp. nov., the causative agent of bacterial kidney disease in salmonid fishes. Int J Syst Bacteriol 30:496-502

Schill WB, Phelps SR, Pyle SW (1984) Multilocus electrophoretic assessment of the genetic structure and diversity of Yersinia ruckeri. Appl Environ Microbiol 48:975-979

Selander RK, Caugant DA, Ochman H, Musser JM, Gilmour MN, Whittam TS (1986) Methods of multilocus enzyme electrophoresis for bacterial population genetics and systematics. App Environ Microbiol 51:873-884

Selander RK, McKinney RM, Whittam TS, Bibb WF, Brenner

Responsible Subject Editor: D. W. Bruno, Aberdeen, Scotland, UK
DJ, Nolte FS, Pattison PE (1985) Genetic structure of populations of Legionella pneumophila. I Bacteriol 163: 1021-1037

Shaw CR, Prasad R (1970) Starch gel electrophoresis of enzymes, a compilation of recipes. Biochem Genet 4: $297-320$

Starliper CE, Phelps SR, Schill WB (1989) Genetic relatedness of Vibro anguillarum and Vibrio ordalii. Microbios Lett 40 : $25-30$

Starliper CE, Schill WB, Shotts Jr EB, Waltman WD (1988) Isozyme analysis of Edwardsiella ictaluri. Microbios Lett $37: 81-87$

Wasem CF, McCarthy CM, Murray LW (1991) Multilocus enzyme electrophoresis analysis of the Mycobacterium avium complex and other mycobacteria. J Clin Microbiol $29: 264-271$

Manuscript first received: March 25, 1996

Revised version accepted: September 2, 1996 